ISSN 1678-3921

Journal homepage: www.embrapa.br/pab

For manuscript submission and journal contents, access: www.scielo.br/pab

\author{
Marco André Grohskopf $\mathrm{f}^{(1 凶)}$, \\ Juliano Corulli Corrêa(2) \\ Dirceu Maximino Fernandes ${ }^{(1)}$, \\ Vinícius de Melo Benites ${ }^{(3)}$, \\ Paulo César Teixeira(3) and \\ Caio Vilela $\mathrm{Cruz}^{(1)}$ \\ (1) Universidade Estadual Paulista Júlio de \\ Mesquita Filho, Campus de Botucatu, Rua \\ José Barbosa de Barros, № 1.780, Fazenda \\ Experimental Lageado, CEP 18160-307 \\ Botucatu, SP, Brazil. \\ E-mail: marcogrohskopf@gmail.com, \\ dmfernades@fca.unesp.br, \\ caiovilelac@hotmail.com \\ (2) Embrapa Suínos e Aves, BR-153, Km 110, \\ Distrito de Tamanduá, Caixa Postal 321, \\ CEP 89715-899 Concórdia, SC, Brazil. \\ E-mail: juliano.correa@embrapa.br \\ (3) Embrapa Solos, Rua Jardim Botânico, \\ no 1.024, Jardim Botânico, CEP 22460-000 \\ Rio de Janeiro, RJ, Brazil. \\ E-mail: vinicius.benites@embrapa.br, \\ paulo.c.teixeira@embrapa.br \\ $\bowtie$ Corresponding author
}

Received

January 12, 2018

Accepted

April 29, 2019

How to cite

GROHSKOPF, M.A.; CORREA, J.C.; FERNANDES, D.M.; BENITES, V. de M.; TEIXEIRA, P.C.; CRUZ, C.V. Phosphate fertilization with organomineral fertilizer on corn crops on a Rhodic Khandiudox with a high phosphorus content. Pesquisa Agropecuária Brasileira, v.54, e00434, 2019. DOI: https://doi. org/10.1590/S1678-3921.pab2019.v54.00434.

\section{Phosphate fertilization with organomineral fertilizer on corn crops on a Rhodic Khandiudox with a high phosphorus content}

\begin{abstract}
The objective of this work was to evaluate the nutritional content and grain yield of three corn (Zea mays) crops in response to phosphate fertilization with an organomineral fertilizer based on poultry litter or a mineral fertilizer, when cultivated on a Rhodic Khandiudox with a high initial phosphorus content. The experiment was carried out in the field in a randomized complete block design in a $2 \times 4+1$ factorial arrangement (organomineral or mineral fertilizer $\times 20,40$, 60, or $80 \mathrm{~kg} \mathrm{ha}^{-1} \mathrm{P}+$ control treatment with no phosphate fertilization), with four replicates each. Available $\mathrm{P}$ and total organic carbon (TOC) contents in the soil at the end of the crop cycle, plant tissue $\mathrm{P}$ contents, and grain yield were determined. The agronomic efficiency index (AEI) was estimated based on corn grain yield. After three harvests, soil available $\mathrm{P}$ and TOC contents did not increase significantly due to fertilizer use, but were directly related to $\mathrm{P}$ doses. In a Rhodic Khandiudox with a high initial $\mathrm{P}$ content, the use of an organomineral fertilizer based on poultry litter promotes higher corn crop yield, with an AEI 20\% higher than that of the mineral fertilizer.
\end{abstract}

Index terms: agronomic efficiency, fertilization, mineral fertilizer, organic waste.

\section{Adubação fosfatada com fertilizante organomineral em cultivo de milho em Nitossolo Vermelho com elevado teor de fósforo}

Resumo - O objetivo deste trabalho foi avaliar o teor nutricional e a produtividade de grãos de três cultivos de milho (Zea mays) em resposta à adubação fosfatada com fertilizante organomineral à base de cama de aves ou mineral, quando cultivado em Nitossolo Vermelho Distroférrico com elevado teor inicial de fósforo. $\mathrm{O}$ experimento foi conduzido em campo, em delineamento de blocos ao acaso, em arranjo fatorial $2 \times 4+1$ (fertilizantes organomineral ou mineral $\times 20,40,60$ ou $80 \mathrm{~kg} \mathrm{ha}^{-1}$ de $\mathrm{P}+$ controle sem adubação fosfatada), com quatro repetições cada um. Foram determinados os teores de $\mathrm{P}$ disponível e carbono orgânico total (COT) no solo ao final do ciclo da cultura, os teores de $\mathrm{P}$ no tecido vegetal e a produtividade de grãos. $\mathrm{O}$ índice de eficiência agronômica (IEA) foi estimado com base na produtividade de grãos. Após três safras, os teores de P disponível e COT no solo não aumentaram significativa com uso dos fertilizantes, mas apresentaram relação direta com as doses de P. Em um Nitossolo Vermelho Distroférrico com elevado teor inicial de P, o uso de fertilizante organomineral à base de cama de aves proporciona maior produtividade de milho, com IEA 20\% superior ao do fertilizante mineral.

Termos para indexação: eficiência agronômica, fertilização, fertilizante mineral, resíduo orgânico. 


\section{Introduction}

New inputs for soil amendment and crop fertilization are strategic for the Brazilian agribusiness because approximately $75 \%$ of the used fertilizers are imported and composed of inorganic mineral sources (ANDA, 2016). One of the strategies proposed to reverse this scenario is applying new fertilizers and good crop fertilization practices (Corrêa et al., 2018).

Phosphorus is the most limiting nutrient for biomass productivity in tropical soils, where less than $0.1 \% \mathrm{P}$ is found in solution (Fink et al., 2016), particularly in oxidic soils with a high adsorption capacity for mineral surfaces (Shen et al., 2011). In addition, only a small proportion of phosphate ions form soluble complexes (Shuai \& Zinati, 2009; Bolan et al., 2013). In those soils, adsorption and precipitation reactions control the fate of $\mathrm{P}$ from fertilizers (Mclaughlin et al., 2011; Montalvo et al., 2015), which explains the frequent applications of high $\mathrm{P}$ doses.

However, in some Brazilian regions, such as in the west of the state of Santa Catarina, due to the intensive soil use during the last decades and the high fertilizer doses applied, soils have become highly fertile and may present varying response patterns to the different types of fertilizers. Considering the constant increase in the yield potential of new cultivars, increasing the efficiency of fertilizer use is challenging and requires the establishment of fertilization criteria to supply the crop's nutritional requirements, taking into account their high nutrient output, while maintaining high soil fertility (Lacerda et al., 2015; Corrêa et al., 2018).

Among the strategies to increase the efficiency of phosphate fertilizers, the use of alternative organic sources to support or complement their formulation stands out (Sá et al., 2017). In soils with high P adsorption, one of the benefits of organomineral fertilizers, compared with the mineral ones, is related to the efficiency of $\mathrm{P}$ use by plants due to the presence of organic compounds that may reduce $\mathrm{P}$ fixation during the soil mineral phase and increase the availability of the nutrient to the plants, especially in their early stages of development (Fernandes et al., 2015).

Of the available organic sources, poultry litter is the most frequently used organic fertilizer in several regions of Brazil because it is widely available, easy to handle, and contains high nutrient levels (Rogeri et al., 2016). The commercial fertilizer formulations based on this organic waste allow supplying nutrients to soil- plant systems and can be transported greater distances from the intensive poultry-production regions (Morais \& Gatiboni, 2015; Corrêa et al., 2018). However, it is still necessary to evaluate if the inclusion of poultry litter in organomineral fertilizer formulations, compared with soluble inorganic mineral fertilizers, changes the response of the $\mathrm{P}$ available in highly fertile soils.

Organomineral fertilizers in solid form have been shown to result in similar or better crop yield than mineral sources (Babalola et al., 2007; Corrêa et al., 2018). However, there are few studies on organominerals as crop fertilizers, requiring detailed researches on soils with different chemical and physical characteristics to optimize their use.

The objective of this work was to evaluate the nutritional content and grain yield of three corn crops in response to phosphate fertilization with an organomineral fertilizer based on poultry litter or a mineral fertilizer, when cultivated on a Rhodic Khandiudox with a high initial phosphorus content.

\section{Materials and Methods}

The experiment was carried out under field conditions between 2013 and 2016 in an experimental area located in the municipality of Concórdia, in the state of Santa Catarina, Brazil $\left(27^{\circ} 14^{\prime} 2^{\prime}\right.$ 'S, $52^{\circ} 1^{\prime} 40^{\prime \prime} \mathrm{W}$, at $569 \mathrm{~m}$ altitude). The climate of the region is subtropical humid (Cfa), according to Köppen's classification. Monthly data on maximum and minimum temperatures and rainfall during the experimental period were collected at a meteorological station located approximately 300 $\mathrm{m}$ from the experimental area (Figure 1).

The soil in the experimental area is basaltic and classified as a Nitossolo Vermelho Distroférrico, i.e., a Rhodic Khandiudox, according to Santos et al. (2013). At the start of the experiment, the following chemical characteristics were determined: $5.0 \mathrm{pH}_{(\mathrm{H} 2 \mathrm{O})}$; $32.7 \mathrm{~g} \mathrm{dm}^{-3}$ soil organic matter; $2.2 \mathrm{~g} \mathrm{dm}^{-3}$ total $\mathrm{N}$; $60,35,15$, and $40 \mathrm{mmol}_{\mathrm{c}} \mathrm{dm}^{-3} \mathrm{Ca}, \mathrm{Mg}, \mathrm{K}$, and $\mathrm{H}+\mathrm{Al}$, respectively; $102 \mathrm{mg} \mathrm{dm}^{-3}$ available $\mathrm{P}$ (Mehlich-1); base saturation of $71 \%$; and $1.2 \mathrm{~g} \mathrm{~cm}^{-3}$ soil bulk density at $0.0-0.2-\mathrm{m}$ depth. The area had been previously used as pasture, and had been fertilized and amended for a long period of time, which increased the fertility of the soil, originally poor in nutrients.

The experimental design was a randomized complete block in a $2 \times 4+1$ factorial arrangement. The treatments 
consisted of two $\mathrm{P}$ fertilizer sources (organomineral or mineral forms) and four $\mathrm{P}$ doses $(20,40,60$, or 80 $\mathrm{kg} \mathrm{ha}^{-1}$ ), in addition to a control treatment with no phosphate fertilization, with four replicates each. Each experimental unit had a total area of $5.0 \times 6.0 \mathrm{~m}$ and an arable area of $3.2 \times 4.0 \mathrm{~m}$.

The organic basis of the organomineral fertilizer consisted of poultry litter from six consecutive flocks, containing 20, 40, and $22 \mathrm{~g} \mathrm{~kg}^{-1}$ total $\mathrm{N}, \mathrm{P}_{2} \mathrm{O}_{5}$, and $\mathrm{K}_{2} \mathrm{O}$ on a dry matter basis, which were taken into account in the formulation of the fertilizer. The mineral source for the organomineral mixture was powdered monoammonium phosphate $\left(\mathrm{NH}_{4} \mathrm{H}_{2} \mathrm{PO}_{4}\right.$ with $48 \%$ $\mathrm{P}_{2} \mathrm{O}_{5}$ and $10 \% \mathrm{~N}$ ), in order to achieve 05-20-02 N- $\mathrm{P}_{2} \mathrm{O}_{5}-$ $\mathrm{K}_{2} \mathrm{O}$. Before the granulation of the organomineral fertilizer, poultry litter was micronized, i.e., ground and sieved to $1.0-\mathrm{mm}$ particle size.

After the addition of $1 \%(\mathrm{~m} / \mathrm{m})$ bentonite, the used organic and mineral materials were ground, weighed, mixed, and homogenized to obtain the tested organomineral formulations. The resulting mixtures were then granulated in a pan granulator at a constant rotation and inclination. Neutral calcium silicate water solution at $0.5 \%$ was sprayed to humidify and bind the mixtures during the granulation process. After granulation, the organomineral fertilizer was sieved

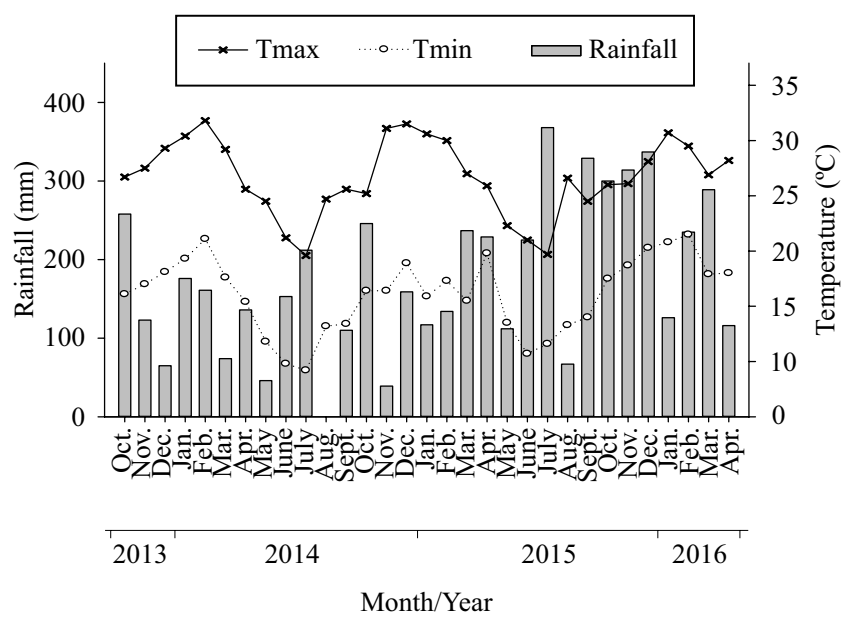

Figure 1. Average maximum (Tmax) and minimum (Tmin) air temperatures and cumulative rainfall recorded during the experimental months in the municipality of Concórdia, in the state of Santa Catarina, Brazil. through 1- and 4-mm meshes, and the material retained between the two sieves was separated and dried in a forced-air ventilation oven at $65^{\circ} \mathrm{C}$ for 48 hours.

The mineral fertilizer contained the same monoammonium phosphate used in the organomineral fertilizer at the volumes required to obtain the corresponding $\mathrm{P}$ doses of each treatment. During each crop cycle, $80 \mathrm{~kg} \mathrm{ha}^{-1} \mathrm{~K}_{2} \mathrm{O}$ were added as potassium chloride during sowing and $140 \mathrm{~kg} \mathrm{ha}^{-1} \mathrm{~N}$ as urea by topdressing. It should be pointed out that the fertilizer added at sowing was applied in the furrow at $0.04-\mathrm{m}$ side distance and depth from the sowing row.

The Celeron TL corn cultivar, a simple earlymaturing hybrid, was used for the 2013/2014, 2014/2015, and 2015/2016 crop seasons. At seeding, $0.80-\mathrm{m}$ spacing between rows and 5.8 seeds per meter were used to obtain a stand of 60,000 plants per hectare. In the winter of 2014 and 2015, in the second half of April, common oat (Avena sativa L.) was sown, without fertilization, at a seed density of $50 \mathrm{~kg} \mathrm{ha}^{-1}$ or approximately +80 seeds per meter at $0.20-\mathrm{m}$ row spacing. Corn and common oat plants were desiccated 14 days before sowing, using 1,800 g ha $^{-1}$ a.i. glyphosate, and invasive plants were manually controlled during the initial development period of both crops.

Corn was manually collected from two rows, which were $2 \mathrm{~m}$ long and spaced at $0.8 \mathrm{~m}$, totaling $3.2 \mathrm{~m}^{2}$, during all evaluated crop years. Then, plants were manually thrashed, and wet grains were weighed and dried. The straw and grains were separated, and the harvested grains were weighed for yield calculation (grains per hectare), corrected to 13\% humidity.

The agronomic efficiency of the organomineral fertilizer at the applied $\mathrm{P}$ doses was evaluated by the agronomic efficiency index (AEI), which compares the crop grain yields obtained with the organomineral fertilizer and with the mineral fertilizer (monoammonium phosphate) at the same $\mathrm{P}$ doses. The AEI was calculated using the equation: AEI $(\%)=$ [(Organomineral fertilizer $r_{\text {test dose }}-$ dose 0) / (Mineral fertilizer $_{\text {test dose }}-$ dose 0$\left.)\right] \times 100$.

The blade portion of 30 corn leaves opposite and below the ear was collected when $50 \%$ of the plants were in the tassel formation stage, in order to determine tissue P content, as described by Silva et al. (2016). The collected plant tissues were dried in a forcedair ventilation oven at $65^{\circ} \mathrm{C}$ until constant weight. 
Samples were then ground for $\mathrm{P}$ content determination following the method of Tedesco et al. (1995).

Depth-stratified soil sampling was carried out at the end of the crop cycle in 2016 at the $0.0-0.1,0.1-0.2$, and $0.0-0.2-\mathrm{m}$ depths. At each depth, two randomly collected samples between rows and one from the row were pooled into a single sample. The pooled samples were air-dried and sieved on a 2-mm mesh, and then analyzed for organic carbon content using the Flash 2000 CHNS/O elemental analyzer (Thermo Fisher Scientific, Waltham, MA, USA). Organic carbon was used as the main parameter for the evaluation of soil quality and response to fertility management. Available $\mathrm{P}$ content was determined according to Tedesco et al. (1995).

Data were analyzed for homoscedasticity and normality. After the statistical parametric assumptions were met, treatment means were compared by Tukey's test, at 5\% probability, when global F-test results were significant. In addition, the regression analysis was performed to determine parameter behavior in response to the application of the different $\mathrm{P}$ doses via organomineral and mineral fertilizers.

\section{Results and Discussion}

There was no influence of $\mathrm{P}$ fertilizer type on the total organic carbon (TOC) content of the evaluated soil strata (Table 1). However, TOC content increased with soil depth as $\mathrm{P}$ doses increased, independently of fertilizer type.

$\mathrm{P}$ dose had a positive cubic effect on TOC content in the $0.0-0.1-\mathrm{m}$ layer, which presented the highest TOC content. In the $0.1-0.2$ and $0.0-0.2-\mathrm{m}$ layers, $\mathrm{P}$ dose had a positive quadratic effect, with maximum points estimated at 50 and 45 and 50 and $40 \mathrm{~kg} \mathrm{ha}^{-1} \mathrm{P}$ for the organomineral and mineral fertilizers, respectively (Table 1).

Since the evaluated soil had been fertilized for a long time, the increasing $\mathrm{P}$ doses of the organomineral and mineral fertilizers applied during the three experimental years did not significantly increase soil organic carbon content. It should be noted that, in highly fertile soils with a long history of use in soilpreservation systems, the stability of most of their chemical and physical attributes makes it difficult to detect responses to fertilizer application in the short and medium term (Costa et al., 2011; Corrêa et al., 2018). In the case of the Rhodic Khandiudox, its high specific surface and strong aggregation allow accumulating and storing carbon in the entire soil profile, which, together

Table 1. Organic carbon content in the 0.0-0.1, 0.1-0.2 and 0.0-0.2-m layers of a Rhodic Khandiudox after three corn (Zea mays) harvests in 2013/2014, 2014/2015, and 2015/2016, in response to the application of different phosphorous doses (0, 20, $40,60,80 \mathrm{~kg} \mathrm{ha}^{-1}$ ) of an organomineral fertilizer based on poultry litter or of a mineral fertilizer.

\begin{tabular}{|c|c|c|c|c|c|c|c|}
\hline \multirow[t]{2}{*}{ Fertilizer } & \multicolumn{5}{|c|}{ Organic carbon content $\left(\mathrm{g} \mathrm{kg}^{-1}\right)$} & \multirow[t]{2}{*}{ Regression equation $^{(1)}$} & \multirow[t]{2}{*}{$\mathrm{R}^{2}$} \\
\hline & 0 & 20 & 40 & 60 & 80 & & \\
\hline & \multicolumn{5}{|c|}{$0.0-0.1-\mathrm{m}$ layer } & & \\
\hline Organomineral & 27.2 & 28.8 & 29.4 & 31.8 & 27.6 & $\hat{y}=27.4-0.04 x+0.005 x^{2}-0.00006 x^{3}$ & 0.76 \\
\hline Mineral & 27.2 & 28.4 & 29.6 & 32.9 & 26.4 & $\hat{y}=27.4-0.2 x+0.01 x^{2}-0.0001 x^{3}$ & 0.79 \\
\hline \multirow[t]{2}{*}{ Mean } & 27.2 & 28.6 & 29.5 & 32.4 & 27.1 & $\hat{y}=27.4-0.1 x+0.008 x^{2}-0.00008 x^{3}$ & 0.78 \\
\hline & \multicolumn{5}{|c|}{$0.1-0.2-\mathrm{m}$ layer } & & \\
\hline Organomineral & 17.4 & 18.4 & 20.0 & 18.9 & 18.5 & $\hat{y}=17.3+0.1 x-0.001 x^{2}$ & 0.70 \\
\hline Mineral & 17.4 & 19.0 & 19.1 & 19.6 & 18.1 & $\hat{y}=17.4+0.09 x-0.001 x^{2}$ & 0.81 \\
\hline \multirow[t]{2}{*}{ Mean } & 17.4 & 18.7 & 19.6 & 19.2 & 18.3 & $\hat{y}=17.4+0.09 x-0.001 x^{2}$ & 0.89 \\
\hline & \multicolumn{5}{|c|}{$0.0-0.2-\mathrm{m}$ layer } & & \\
\hline Organomineral & 22.3 & 23.6 & 24.8 & 25.3 & 23.0 & $\hat{y}=22.0+0.1 x-0.001 x^{2}$ & 0.78 \\
\hline Mineral & 22.3 & 23.8 & 24.3 & 26.3 & 22.3 & $\hat{y}=21.9+0.1 x-0.002 x^{2}$ & 0.58 \\
\hline Mean & 22.3 & 23.7 & 24.6 & 25.8 & 22.6 & $\hat{y}=22.0+0.1 x-0.002 x^{2}$ & 0.67 \\
\hline
\end{tabular}

(1) Significant at $1 \%$ probability. 
with the no-tillage management system, causes greater organic carbon and nutrient accumulation in the most superficial layer in response to fertilizer application (Tewolde et al., 2008; Watts et al., 2010; Mafra et al., 2014).

After three corn harvests, no differences were observed in available $\mathrm{P}$ between the organomineral and mineral fertilizers at the same $\mathrm{P}$ dose. However, independently of fertilizer, available $\mathrm{P}$ content increased as a function of $\mathrm{P}$ dose in all assessed layers (Table 2). Although the soil P levels obtained in all treatments were very high according to the ranges proposed by Silva et al. (2016), P availability in oxidic soils is strictly controlled by the mineral phase, when this nutrient is strongly adsorbed, and by the large number of adsorbent sites present in the entire profile of this soil type (Shuai \& Zinati, 2009; Bortolon et al., 2016; Fink et al., 2016), which allows controlling P fixation and release from fertilizers even when soil $\mathrm{P}$ content is high.

The higher $\mathrm{P}$ contents determined in the $0.0-0.1-$ $\mathrm{m}$ layer may be explained by the low mobility of $\mathrm{P}$ in oxidic soils, which, coupled with the planting system, favors the accumulation of nutrients in the most superficial layer (Fink et al., 2016). However, available $\mathrm{P}$ content was also very high in the 0.1-0.2-m layer, which may be attributed to the long history of soil use, allowing the vertical displacement of $\mathrm{P}$ in the soil profile, despite the preservationist management system adopted, probably due the saturation of adsorbent sites in the superficial layer or to the formation of specific channels (Corrêa et al., 2018).

The effects of $\mathrm{P}$ doses via both organomineral and mineral fertilizers on available $P$ contents in the 0.0 $0.1,0.1-0.2$, and $0.0-0.2-\mathrm{m}$ layers are shown in Table 2 . In the $0.0-0.1-\mathrm{m}$ layer, $\mathrm{P}$ doses had an increasing quadratic effect, with maximum $\mathrm{P}$ availability estimated at 62 and $63 \mathrm{~kg} \mathrm{ha}^{-1} \mathrm{P}$ with the organomineral and mineral fertilizers, respectively. However, in the $0.1-0.2$ and $0.0-0.2-\mathrm{m}$ layers, $\mathrm{P}$ doses had a positive cubic effect on $\mathrm{P}$ availability. Therefore, increasing $\mathrm{P}$ doses using organomineral and mineral fertilizers allowed increasing available $\mathrm{P}$ soil contents after three years of corn cultivation, when compared with the nonfertilized soil (control), which already presented high available P contents (Table 2). Considerable increases in available $\mathrm{P}$ contents were observed for both studied fertilizers using $\mathrm{P}$ doses of $20 \mathrm{~kg} \mathrm{ha}^{-1}$ and higher.

No differences in leaf $\mathrm{P}$ content were detected between $\mathrm{P}$ fertilizer type and doses (Table 3). Leaf $\mathrm{P}$ contents ranged from 2.6 to $3.3 \mathrm{~g} \mathrm{~kg}^{-1}$, which are within the interval of 2.0 to $4.0 \mathrm{~g} \mathrm{~kg}^{-1}$ considered adequate for corn crops according to Silva et al. (2016). The adequate leaf $\mathrm{P}$ contents determined in all treatments,

Table 2. Available phosphorous content in the $0.0-0.1,0.1-0.2$ and $0.0-0.2-\mathrm{m}$ layers of a Rhodic Khandiudox after three corn (Zea mays) harvests in 2013/2014, 2014/2015, and 2015/2016, in response to the application of different P doses (0, 20, $40,60,80 \mathrm{~kg} \mathrm{ha}^{-1}$ ) of an organomineral fertilizer based on poultry litter or of a mineral fertilizer.

\begin{tabular}{|c|c|c|c|c|c|c|c|}
\hline \multirow[t]{2}{*}{ Fertilizer } & \multicolumn{5}{|c|}{ Available $\mathrm{P}\left(\mathrm{mg} \mathrm{kg}^{-1}\right)$} & \multirow[t]{2}{*}{ Regression equation $^{(1)}$} & \multirow[t]{2}{*}{$\mathrm{R}^{2}$} \\
\hline & 0 & 20 & 40 & 60 & 80 & & \\
\hline \multicolumn{8}{|c|}{$0.0-0.1-\mathrm{m}$ layer } \\
\hline Organomineral & 106.7 & 114.2 & 119.2 & 123.2 & 119.8 & $\hat{y}=106.3+0.5 x-0.004 x^{2}$ & 0.87 \\
\hline Mineral & 106.7 & 115.8 & 118.3 & 120.0 & 120.5 & $\hat{y}=107.3+0.4 x-0.003 x^{2}$ & 0.88 \\
\hline Mean & 106.7 & 115.0 & 118.8 & 121.6 & 120.2 & $\hat{y}=106.8+0.5 x-0.004 x^{2}$ & 0.90 \\
\hline \multicolumn{8}{|c|}{$0.1-0.2-\mathrm{m}$ layer } \\
\hline Organomineral & 98.3 & 109.2 & 108.2 & 100.0 & 100.1 & $\hat{y}=98.2+1.1 x-0.03 x^{2}-0.0002 x^{3}$ & 0.88 \\
\hline Mineral & 98.3 & 101.7 & 100.8 & 99.2 & 103.7 & $\hat{y}=98.2+0.4 x-0.01 x^{2}-0.0001 x^{3}$ & 0.89 \\
\hline Mean & 98.3 & 105.4 & 104.5 & 99.6 & 101.9 & $\hat{y}=98.2+0.8 x-0.02 x^{2}-0.0002 x^{3}$ & 0.88 \\
\hline \multicolumn{8}{|c|}{$0.0-0.2-\mathrm{m}$ layer } \\
\hline Organomineral & 102.5 & 111.7 & 113.7 & 111.6 & 110.0 & $\hat{y}=102.5+0.7 x-0.01 x^{2}-0.00008 x^{3}$ & 0.90 \\
\hline Mineral & 102.5 & 108.8 & 109.6 & 109.6 & 112.1 & $\hat{y}=102.5+0.5 x-0.01 x^{2}-0.00008 x^{3}$ & 0.90 \\
\hline Mean & 102.5 & 110.2 & 111.6 & 110.5 & 111.1 & $\hat{y}=102.5+0.6 x-0.01 x^{2}-0.00008 x^{3}$ & 0.92 \\
\hline
\end{tabular}

${ }^{(1)}$ Significant at $1 \%$ probability. 
including the control without $\mathrm{P}$ fertilization, may be attributed to the high initial available $\mathrm{P}$ content in the soil (102 $\left.\mathrm{mg} \mathrm{kg}^{-1}\right)$, which allowed achieving good yield even when no fertilizer was applied.

Corn grain yield results are shown in Figure 2. The organomineral fertilizer at all tested $\mathrm{P}$ doses promoted higher yield in the 2013/2014 and 2015/2016 harvests, as well as in the sum of all harvests. However, in the 2014/2015 harvest, corn grain yield differed between fertilizers at the dose of 60 and $80 \mathrm{~kg} \mathrm{ha}^{-1} \mathrm{P}$, when significantly higher yields were obtained with the organomineral fertilizer. This result may be explained by the presence of organic matter in the poultry litter used for the production of the organomineral fertilizer, which may cause a slower $\mathrm{P}$ release or a lower $\mathrm{P}$ retention in soil colloids and, consequently, greater $\mathrm{P}$ use by the plants, particularly during their initial development (Fernandes et al., 2015; Corrêa et al., 2018). Moreover, the organic matter in the poultry litter may have improved the physical and biological properties of the soil around the granules, favoring plant development and, therefore, yield.

The amount of available $\mathrm{P}$ in the organomineral fertilizer that is not absorbed by the plants may bind to the crystalline forms of the $\mathrm{Fe}$ and $\mathrm{Al}$ oxides present in the Rhodic Khandiudox, which, coupled with a high initial $\mathrm{P}$ content, may favor the vertical movement of the nutrient to deeper soil layers until its adsorption to a binding site. Therefore, the available $\mathrm{P}$ and the low carbon contents of the organomineral fertilizer minimized the effect of the competition between organic anions and $\mathrm{P}$ for adsorption sites in the Rhodic Khandiudox, characterized by a built-up fertility. Although this effect is limited to a few days after the application of the fertilizer, it was sufficient to allow a better initial plant growth than the mineral source, explaining the higher yield obtained.

In the three evaluated harvests, corn grain yield response to the application of increasing $\mathrm{P}$ doses via both the organomineral and mineral fertilizers is described by a positive quadratic function (Figure 2). The constructed graphs show that, for a same corn grain yield, a lower P dose needs to be applied when using the organomineral fertilizer. For the organomineral and mineral fertilizers, respectively, the highest corn grain yields were obtained at the estimated $\mathrm{P}$ doses of: 73 and $65 \mathrm{~kg} \mathrm{ha}^{-1}$ in the 2013/2014 harvest, with maximum yields of 10,045 and $8,752 \mathrm{~kg} \mathrm{ha}^{-1} ; 80$ and 72

Table 3. Leaf tissue phosphorous content in three harvests of corn (Zea mays) cultivated on a Rhodic Khandiudox fertilized with different $\mathrm{P}$ doses $\left(0,20,40,60,80 \mathrm{~kg} \mathrm{ha}^{-1}\right)$ of an organomineral fertilizer based on poultry litter or of a mineral fertilizer.

\begin{tabular}{|c|c|c|c|c|c|c|}
\hline \multirow[t]{2}{*}{ Fertilizer } & \multicolumn{5}{|c|}{ Leaf tissue $\mathrm{P}$ content $\left(\mathrm{g} \mathrm{kg}^{-1}\right)$} & \multirow[t]{2}{*}{ Regression equation $^{(1)}$} \\
\hline & 0 & 20 & 40 & 60 & 80 & \\
\hline \multicolumn{7}{|c|}{ 2013/2014 harvest } \\
\hline Organomineral & 2.8 & 3.0 & 2.8 & 2.8 & 2.8 & $\hat{y}=2.8$ \\
\hline Mineral & 2.8 & 3.0 & 2.7 & 3.2 & 2.9 & $\hat{y}=2.9$ \\
\hline Mean & 2.8 & 3.0 & 2.8 & 3.0 & 2.8 & $\hat{y}=2.9$ \\
\hline \multicolumn{7}{|c|}{$2014 / 2015$ harvest } \\
\hline Organomineral & 2.6 & 2.8 & 2.7 & 3.0 & 3.0 & $\hat{y}=2.8$ \\
\hline Mineral & 2.6 & 2.7 & 2.9 & 3.4 & 3.1 & $\hat{y}=2.9$ \\
\hline Mean & 2.6 & 2.8 & 2.8 & 3.2 & 3.0 & $\hat{y}=2.9$ \\
\hline \multicolumn{7}{|c|}{$2015 / 2016$ harvest } \\
\hline Organomineral & 2.6 & 2.6 & 2.8 & 3.2 & 3.2 & $\hat{y}=2.9$ \\
\hline Mineral & 2.6 & 2.5 & 2.7 & 3.3 & 3.0 & $\hat{y}=2.8$ \\
\hline Mean & 2.6 & 2.6 & 2.8 & 3.2 & 3.1 & $\hat{y}=2.9$ \\
\hline \multicolumn{7}{|c|}{ Average of three harvests } \\
\hline Organomineral & 2.7 & 2.8 & 2.8 & 3.0 & 3.0 & $\hat{y}=2.9$ \\
\hline Mineral & 2.7 & 2.7 & 2.8 & 3.3 & 3.0 & $\hat{y}=2.9$ \\
\hline Mean & 2.7 & 2.8 & 2.8 & 3.2 & 3.0 & $\hat{y}=2.9$ \\
\hline
\end{tabular}

(1) Significant at $1 \%$ probability. 
$\mathrm{kg} \mathrm{ha}^{-1}$ in the 2014/2015 harvest, with maximum yields of 9,466 and $8,691 \mathrm{~kg} \mathrm{ha}^{-1}$; and 80 and $80 \mathrm{~kg} \mathrm{ha}^{-1}$ in the $2015 / 2016$ harvest, with maximum yields of 9,392 and $8,827 \mathrm{~kg} \mathrm{ha}^{-1}$.

Organomineral fertilizers in the solid form result in crop yields that are similar to or better than those obtained with mineral fertilizers (Babalola et al., 2007; Corrêa et al., 2018). However, there are still few studies on organomineral fertilizers, particularly regarding their formulation and interactions with other organic materials, as well as plant responses when they are applied to different soil classes.

The AEI, calculated based on corn grain yield, showed better values, higher than $100 \%$, for the organomineral fertilizer at all $\mathrm{P}$ doses (Table 4). This result indicates the higher efficiency of this fertilizer, except with the P dose of $20 \mathrm{~kg} \mathrm{ha}^{-1}$ in the 2014/2015 harvest, when the mineral fertilizer was more efficient.

Considering the average of the three corn harvests, the organomineral fertilizer was $22,17,18$, and $28 \%$ more efficient than the mineral fertilizer at the $\mathrm{P}$ doses of 20,40, 60 and $80 \mathrm{~kg} \mathrm{ha}^{-1}$, respectively (Table 4). Furthermore, the values obtained for the AEI based on the sum of the corn grain yields of the three harvests are consistent with those for the individual harvests. Therefore, the results of the present study show that the organomineral fertilizer is, on average, approximately $20 \%$ more efficient than the mineral fertilizer, when applied on a Rhodic Khandiudox with high available P content.
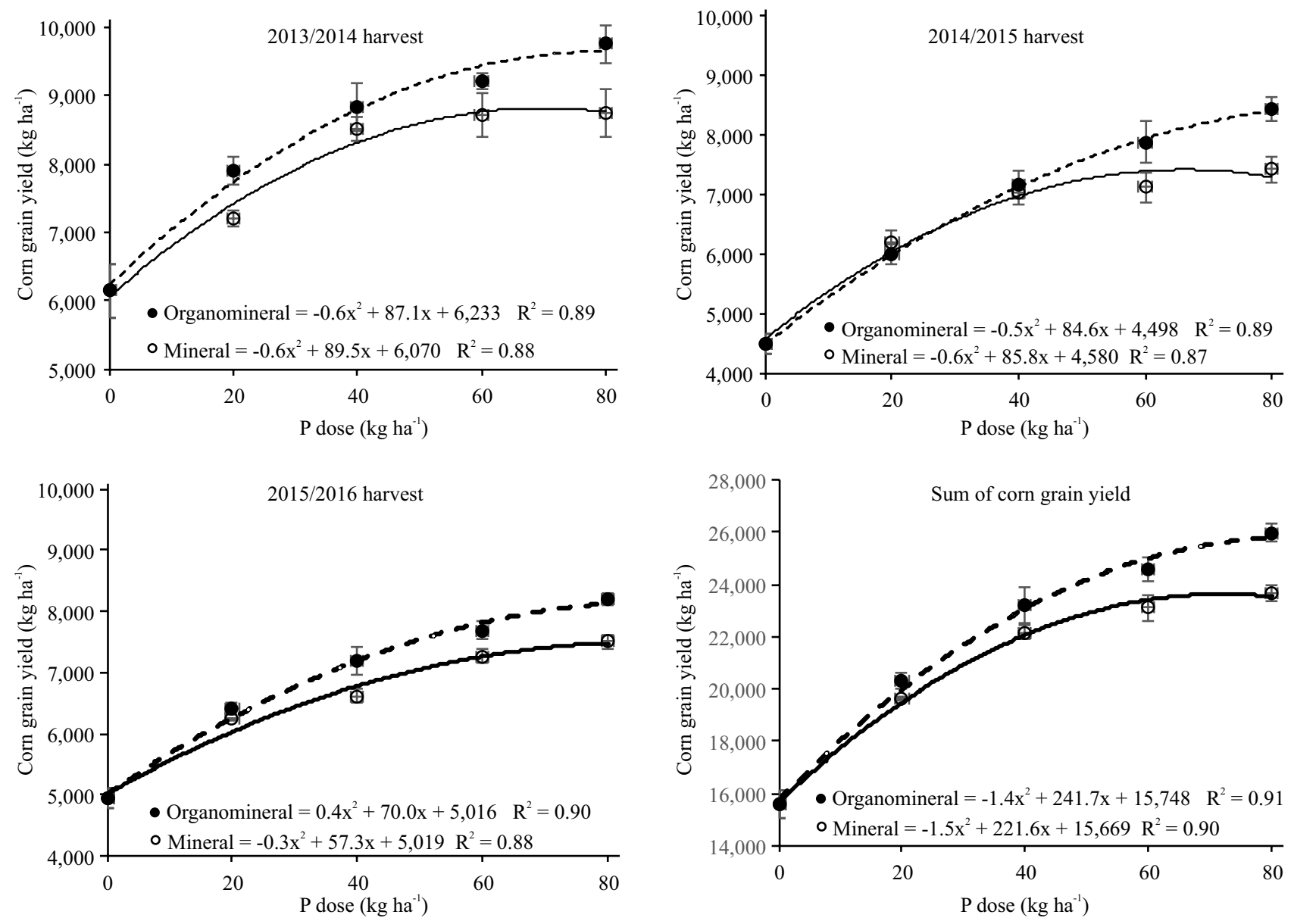

Figure 2. Corn (Zea mays) grain yield obtained in three harvests in 2013/2014, 2014/2015, and 2015/2016, when cultivated on a Rhodic Khandiudox with a high P content (built-up fertility). Average of four replicates. Vertical bars represent the standard error of the means. 
Table 4. Agronomic efficiency index ${ }^{(1)}$ for corn (Zea mays) yield obtained with different phosphorous doses $(0,20$, $\left.40,60,80 \mathrm{~kg} \mathrm{ha}^{-1}\right)$ of an organomineral fertilizer based on poultry litter or of a mineral fertilizer in the monoammonium phosphate form, in three harvests in 2013/2014, 2014/2015, and 2015/2016.

\begin{tabular}{lccccc}
\hline \multirow{2}{*}{$\begin{array}{l}\text { Corn grain } \\
\text { yield }\end{array}$} & \multicolumn{3}{c}{ Agronomic efficiency index (\%) } & \multirow{2}{*}{ Mean } \\
\cline { 2 - 5 } & 20 & 40 & 60 & 80 & \\
\hline $2013 / 2014$ & $168 \pm 22$ & $113 \pm 18$ & $119 \pm 12$ & $135 \pm 28$ & $134 \pm 21$ \\
$2014 / 2015$ & $88 \pm 11$ & $105 \pm 14$ & $121 \pm 17$ & $124 \pm 10$ & $109 \pm 13$ \\
$2015 / 2016$ & $113 \pm 12$ & $133 \pm 16$ & $118 \pm 9$ & $127 \pm 6$ & $123 \pm 11$ \\
\hline Average & $122 \pm 14$ & $117 \pm 16$ & $118 \pm 13$ & $128 \pm 15$ & $121 \pm 14$ \\
Sum $^{(1)}$ & $117 \pm 10$ & $115 \pm 11$ & $119 \pm 14$ & $129 \pm 7$ & $120 \pm 10$ \\
\hline
\end{tabular}

${ }^{(1)}$ Estimated based on the sum of the corn grain yields obtained in the three evaluated harvests.

\section{Conclusions}

1. The application of organomineral and mineral fertilizers on a Rhodic Khandiudox with a high phosphorous content does not increase total organic carbon or available $\mathrm{P}$ contents; however, there is a direct relationship between $\mathrm{P}$ doses and these soil parameters.

2. In a Rhodic Khandiudox with a high P content, the application of the organomineral fertilizer based on poultry litter promotes higher corn (Zea mays) grain yield, with an agronomic efficiency index $20 \%$ higher than that of the mineral fertilizer.

\section{References}

ANDA. Associação Nacional para Difusão de Adubos. Setor de fertilizantes: anuário estatístico 2016. São Paulo, 2016. Available at: $\quad<$ http://anda.org.br/pdfs/INDICE-ANUARIO-2016.pdf>. Accessed on: July 122017.

BABALOLA, O.; OSHUNSANYA, S.O.; ARE, K. Effects of vetiver grass (Vetiveria nigritana) strips, vetiver grass mulch and an organomineral fertilizer on soil, water and nutrient losses and maize (Zea mays, L.) yields. Soil and Tillage Research, v.96, p.618, 2007. DOI: https://doi.org/10.1016/j.still.2007.02.008.

BOLAN, N.; MAHIMAIRAJA, S.; CHOPPALA, G. Phosphorusarsenic interactions in variable-charge soils in relation to arsenic mobility and bioavailability. Science of the Total Environment, v.463-464, p.1154-1162, 2013. DOI: https://doi.org/10.1016/j. scitotenv.2013.04.016.

BORTOLON, L.; ERNANI, P.R.; BORTOLON, E.S.O.; GIANELLO, C.; ALMEIDA, R.G.O. de; WELTER, S.; ROGERI,
D.A. Degree of phosphorus saturation threshold for minimizing P losses by runoff in cropland soils of Southern Brazil. Pesquisa Agropecuária Brasileira, v.51, p.1088-1098, 2016. DOI: https://doi.org/10.1590/S0100-204X2016000900008.

CORREAA, J.C.; REBELLATTO, A.; GROHSKOPF, M.A.; CASSOL, P.C.; HENTZ, P.; RIGO, A.Z. Soil fertility and agriculture yield with the application of organomineral or mineral fertilizers in solid and fluid forms. Pesquisa Agropecuária Brasileira, v.53, p.633-640, 2018. DOI: https://doi.org/10.1590/ s0100-204x2018000500012.

COSTA, M.S.S. de M.; PIVETTA, L.A.; COSTA, L.A. de M.; PIVETTA, L.G.; CASTOLDI, G.; STEINER, F. Atributos físicos do solo e produtividade do milho sob sistemas de manejo e adubações. Revista Brasileira de Engenharia Agrícola e Ambiental, v.15, p.810-815, 2011. DOI: https://doi.org/10.1590/ S1415-43662011000800007.

FERNANDES, D.M.; GROHSKOPF, M.A.; GOMES, E.R.; FERREIRA, N.R.; BÜLL, L.T. Fósforo na solução do solo em resposta à aplicação de fertilizantes fluidos mineral e organomineral. Irriga, v.1, p.14-27, 2015. Edição Especial. DOI: https://doi.org/10.15809/irriga.2015v1n1p14.

FINK, J.R.; INDA, A.V.; BAVARESCO, J.; BARRÓN, V.; TORRENT, J.; BAYER, C. Adsorption and desorption of phosphorus in subtropical soils as affected by management system and mineralogy. Soil \& Tillage Research, v.155, p.62-68, 2016 DOI: https://doi.org/10.1016/j.still.2015.07.017.

LACERDA, J.J. de J.; RESENDE, A.V. de; FURTINI NETO, A.E.; HICKMANN, C.; CONCEIÇÃO, O.P. da. Adubação, produtividade e rentabilidade da rotação entre soja e milho em solo com fertilidade construída. Pesquisa Agropecuária Brasileira, v.50, p.769-778, 2015. DOI: https://doi.org/10.1590/ S0100-204X2015000900005.

MAFRA, M.S.H.; CASSOL, P.C.; ALBUQUERQUE, J.A.; CORRÊA, J.C.; GROHSKOPF, M.A.; PANISSON, J. Acúmulo de carbono em Latossolo adubado com dejeto líquido de suínos e cultivado em plantio direto. Pesquisa Agropecuária Brasileira, v.49, p.630-638, 2014. DOI: https://doi.org/10.1590/S0100$204 X 2014000800007$.

MCLAUGHLIN, M.J.; MCBEATH, T.M.; SMERNIK, R.; STACEY, S.P.; AJIBOYE, B.; GUPPY, C. The chemical nature of $\mathrm{P}$ accumulation in agricultural soils - implications for fertilizer management and design: an Australian perspective. Plant and Soil, v.349, p.69-87, 2011. DOI: https://doi.org/10.1007/s11104011-0907-7.

MONTALVO, D.; DEGRYSE, F.; MCLAUGHLIN, M.J. Agronomic effectiveness of granular and fluid phosphorus fertilizers in Andisols and Oxisols. Soil Science Society of America Journal, v.79, p.577-584, 2015. DOI: https://doi.org/10.2136/sssaj2014.04.0178.

MORAIS, F.A.; GATIBONI, L.C. Phosphorus availability and microbial immobilization in a Nitisol with the application of mineral and organo-mineral fertilizers. Anais da Academia Brasileira de Ciência, v.87, p.2289-2299, 2015. DOI: https://doi.org/10.1590/0001-3765201520140008. 
ROGERI, D.A.; ERNANI, P.R.; MANTOVANI, A.; LOURENÇO, K.S. Composition of poultry litter in Southern Brazil. Revista Brasileira de Ciência do Solo, v.40, e0140697, 2016. DOI: https://doi.org/10.1590/18069657rbcs20140697.

SÁ, J.M. e; JANTALIA, C.P.; TEIXEIRA, P.C.; POLIDORO, J.C.; BENITES, V. de M.; ARAÚJO, A.P. Agronomic and P recovery efficiency of organomineral phosphate fertilizer from poultry litter in sandy and clayey soils. Pesquisa Agropecuária Brasileira, v.52, p.786-793, 2017. DOI: https://doi.org/10.1590/ S0100-204X2017000900011.

SANTOS, H.G. dos; JACOMINE, P.K.T.; ANJOS, L.H.C. dos; OLIVEIRA, V.A. de; LUMBRERAS, J.F.; COELHO, M.R.; ALMEIDA, J.A. de; CUNHA, T.J.F.; OLIVEIRA, J.B. de. Sistema brasileiro de classificação de solos. 3.ed. rev. e ampl. Brasília: Embrapa, 2013. 353p.

SHEN, J.; YUAN, L.; ZHANG, J.; LI, H.; BAI, Z.; CHEN, X.; ZHANG, W.; ZHANG, F. Phosphorus dynamics: from soil to plant. Plant Physiology, v.156, p.997-1005, 2011. DOI: https://doi.org/10.1104/pp.111.175232.

SHUAI, X.; ZINATI, G. Proton charge and adsorption of humic acid and phosphate on goethite. Soil Science Society of America
Journal, v.73, p.2013-2020, 2009. DOI: https://doi.org/10.2136/ sssaj2009.0119.

SILVA, L.S.; GATIBONI, L.C.; ANGHINONI, I.; SOUZA, R.O. (Ed.). Manual de calagem e adubação para os estados do Rio Grande do Sul e de Santa Catarina. [Xanxerê]: Comissão de Química e Fertilidade do Solo - RS/SC, 2016. 376p.

TEDESCO, M.J.; GIANELLO, C.; BISSANI, C.A.A.; BOHNEN, H.; VOLKWEISS, S.J.; Análise de solos, plantas e outros materiais. 2.ed. rev. e ampl. Porto Alegre: UFRGS, 1995. 212p. (UFRGS. Boletim Técnico de Solos, 5).

TEWOLDE, H.; SHANKLE, M.W.; SISTANI, K.R.; ADELI, A.; ROWE, D.E. No-till and convention-till cotton response to broiler litter fertilization in an upland soil: lint yield. Agronomy Journal, v.100, p.502-509, 2008. DOI: https://doi.org/10.2134/ agronj2007.0137.

WATTS, D.B.; TORBERT, H.A.; PRIOR, S.A.; HULUKA, G. Long-term tillage and poultry litter impacts soil carbon and nitrogen mineralization and fertility. Soil Science Society of America Journal, v.74, p.1239-1247, 2010. DOI: https://doi.org/10.2136/sssaj2008.0415. 